\title{
School Climate of Educational Institutions: Design and Validation of a Diagnostic Scale
}

\author{
Sandra Becerra ${ }^{1}$ \\ ${ }^{1}$ Faculty of Education, Universidad Católica at Temuco, Temuco, Chile \\ Correspondence: Sandra Becerra, Faculty of Education, Universidad Católica at Temuco, Manuel, Montt 56, \\ Chile. Tel: 56-45-220-5205. E-mail: sbecerra@uct.cl
}

Received: December 14, 2015 Accepted: January 18, 2016 Online Published: April 26, 2016

doi:10.5539/ies.v9n5p96

URL: http://dx.doi.org/10.5539/ies.v9n5p96

\begin{abstract}
School climate is recognized as a relevant factor for the improvement of educative processes, favoring the administrative processes and optimum school performance. The present article is the result of a quantitative research model which had the objective of psychometrically designing and validating a scale to diagnose the organizational climate of educational institutions.

This study had the participation of 549 teachers and directors from 42 primary and secondary educational establishments of Chile. Diverse procedures were applied for the validation of content and psychometric validation in the various stages of the investigation, obtaining an instrument composed by seven factors and made up of conceptually and statistically consistent items. The complete scale and its sub-scales show adequate reliability, and likewise an appropriate validity, constituting it an instrument of wide use for supporting the process of education administration, and to promote coexistence climates of appreciation and respect among the educational participants.

The complete scale and its subscales permits the understanding that the organizational climate of the educational center is not reduced to the teacher-student relationship, but rather contemplates the dynamic relationships between diverse players, establishing the importance of the joint action between teachers, directives, students, and parents, as well as revealing the importance of some structural organization variables which influence the daily perception of school climate.
\end{abstract}

Keywords: school climate, assessment of school climate, evaluation scale of school climate

\section{Introduction}

Currently, school climate represents a subject of interest and need for a great number of schools; the characteristics and qualities of school climate are relevant for educational institutions all over the world. School climate has become in recent years a construct of high value and interest, recognized and employed by agencies, ministries and educational institutions on an international scale (Thapa, Cohen, Guffey, \& Higgins-D’Alessandro, 2013; López, Bilbao, Ascorra, Moya, \& Morales, 2014).

In coherence, specialized literature argues that the educative climate has relevance for the school organization because of the repercussion which acts in: educational results, identity with the institution, and the psychological wellbeing developed among its members (Boulifa \& Kaaouachi, 2014; Martín-Bris, 2000; Cassasus, 2003; González, 2004; Becerra, Sánchez \& Tapia, 2007; MINEDUC, 2014).

There is a necessity to develop processes of formal, structural diagnosis which institutionally allows the school climate study. This derives from a growing demand for having diagnostic instruments which permit for the advancement in this area.

The present study has as objective to build and establish the psychometric characteristics of validation and reliability of the school climate scale. The aim is to offer a current tool, with adequate psychometric characteristics, which serves as an incentive for other countries, to facilitate the processes of diagnosis and improvement of the school climate, identified as key for the achievement of educational results, (Martín-Bris, 2000; Cassasus, 2003; González, 2004), and contributing centrally to the educational administration. 


\subsection{The Importance of School Climate of Educational Institutions}

The international literature is overwhelming in confirming the direct relationship between school climate and student performance. Countries evaluated as 'successful' and recognized as countries of high academic performance on international school performance tests, such as Finland, Cuba, Canada, and the Republic of Korea, recognize as a determining factor in the attainment of high results the establishment of a positive school climate, which then empowers the organizational commitment, and vitalizes the educative processes (Alarcón \& Romagnoli, 2006). Consistently, in countries such as the United States, Canada, France and Israel "the school climate forms part of the evaluation of educative quality in schools" (López et al., 2014, p. 1112).

In Latin America, the results of the Second Regional Comparative and Explanatory Study on Education (SERCE) performed by UNESCO and the Latin American Laboratory for Assessment of the Quality of Education, developed in 15 countries with the participation of 196,040 students, confirmed that school climate is the most influential variable on students' performance. The influence of the interior conditions of the school demonstrates the important contribution the climate makes on establishments, even above socioeconomic factors, significantly favoring the decrease in learning inequalities associated with social disparity (Organización de las Naciones Unidas para la Educación, Ciencia \& Cultura [UNESCO], 2008).

The positive relationships between educational climate and academic achievement have been confirmed by the PISA test and in Latin America with the data from the SERCE assessment (UNESCO). Both studies prove that the school climate has a relevant mediating effect, being able to decrease the variance explained by each sociocultural level and sociocultural capital of the families over academic performance. It is to say that controlling the effect of socioeconomic levels, the school climate can explain the good scores on academic achievement tests. In Chile's case, the national evaluations showed a significant correlation between schools that obtain high academic scores and the score they achieve on items such as coexistence and school climate, observing as much as a 40 point difference in schools where the students perceived a good educative environment (Ministry of Education Chile [MINEDUC], 2014).

The aforementioned motivates and puts pressure on schools to recognize the necessity to improve the educational climate of their establishment. Multiple records show that the management of educative climate, despite its relevance, is still a pending subject for many countries in Latin America (Claro \& Bedregal, 2003; González, 2006; Becerra \& Murillo, 2009; Esteve, 2006). The national and world contingency has emphasized attention on diverse expressions of mistreatment and abuse in the interpersonal relations of the educative players, constituting a worrying social reality (González, 2006; Claro \& Bedregal, 2003, Fierro, 2013). There are schools where the teaching staff maintains perceptions of an organization that is not capable of taking care of the psychosocial well-being of its members by permitting dysfunctional situations or mistreatment among its members and in the diverse organizational processes (Becerra \& Murillo, 2009).

In many countries general perception exists among teachers, which accounts for the school as an organization, which is not aware or sensible to improving the conditions and the work environment of the members (González, 2006; Claro \& Bedregal, 2003, Becerra, Sánchez, \& Tapia, 2007), thus verifying high levels of teacher exhaustion and displeasure.

School climate possesses an unavoidable value when trying to transform the low levels of satisfaction and the low perception of psychosocial well-being that the teaching staff possesses in the educational organizations on an international and national level (Esteve 2006; Milicic, Arón \& Pesce, 2003, Becerra \& Murillo, 2009). The educational climate influences, in a relevant way, not only the achievement of school results, but also the well-being of students and teachers.

The present study addresses the conceptualization achieved by Caso and Fierro (2013) whose studies confirm the necessity to have an approach to the processes which intervene in this chosen area and use instruments which permit the evaluation and description of this phenomenon in an objective way. The objective evaluation will help the appropriate measurement of the area permitting the establishment of indicators there, and at the same time will deliver clear directions to lead in the improvement of the school (Caso, Díaz, \& Chaparro, 2013)

It has become more necessary to use psychomentrically solid instruments which permit the researchers and the educational institutions "to incorporate the measurement of school climate within the processes of school improvement based on evidence" (López et al., 2014, p. 1112).

The problem is stated as verifying that the scarce information in validated instruments in the area exist. We adhere to the perspective of Lopez (2014) who affirms that in Spanish-speaking countries and Latin America there are few instruments in the area with adequate psychometric characteristics (Aron, Milicic, \& Armijo, 2012). 
It has become "necessary to rely on validated instruments for the Latin American population, which permit for comparative investigation between the countries of the Region, as well as countries of other continents (López et al., 2014, p. 1112).

\subsection{Understanding of the School Climate Construct}

The concept of educational climate has as a precedent the concept of 'organizational climate' like organizations in the labor sphere. The term, organizational climate, comes from the 1960's, when Tagiuri and Litwin affirm that the way that a person carries out a task in his/her organization depends a lot on his/her personal characteristics, as much as the characteristics of the environment in which the person acts. The educational climate construct inherits from the organizational perspective the value of the circular influence between work environment and the people. The concept of school climate is presented as an adaption of the organizational climate construct utilized for productive organizational systems (businesses or factories), even when it is recognized with sensibility that schools possess organizational characteristics and dynamics which are very different from such institutions (López et al., 2014).

There is currently a consensus, referring to the fact that the educational climate symbolizes a construct, or cognitive and collective representation of the kind of relationships that are produced in an organization, conditioned by a series of structural variables specific to the school. The school climate is not a construct which is built from a personal dimension, it is not an individual representation, but rather collectively is made by gathering the perceptions of the actors in regards to the diverse interactions that make up the school context (Becerra, 2009, 2015). This allows for the comprehension of the school climate as a dynamic aspect of the school, in constant movement and change, which is formed by daily situations and actions. In this sense, the everyday school life is the ideal space to analyze and rebuild the climate of the school community.

The school climate of an educational institution is not reduced to the perceptions of teacher-student interaction, but rather considers relationship dynamics between the various players. In this regard, previous studies present that when a school wants to maximize their organizational climate, they must attend to the joint interaction between teachers, directives, students and parents, but principally they must work intentionally with the relationship between the teachers and the directors, since they have been shown to be determining factors and first in significance (Becerra, 2006; Murillo \& Becerra, 2009; Ainscow \& Miles, 2008; Bush \& Glover, 2012)

There currently exists a consensus that recognizing the educational climate construct would be the result of the contacting of two essential elements, on one side the social processes or relationships which occur between members, and on the other side, the influence and reciprocal interaction of the members and the structural characteristics of the organizational environment. The aforementioned in the words of Martín-Bris (2000) and López (2000), leads us to understand the educational climate, like the relational atmosphere, of the educational institution is determined by the personal characteristics of the members and the type of relationships and processes which are developed in the organizational environment. The educational climate constitutes an organizational quality which differs, characterizes and conditions life at the school.

Among the most accepted definitions, we can refer to climate "as a set of psychosocial characteristics of an educational center, determined by those personal or functional factors or structural elements of the institution which, integrated in a specific dynamic process, confer a peculiar style to the school, conditioning the various relational processes which occur therein" (Cere 1993; Becerra, 2006).

Other conceptualizations (Arón, Milicic, \& Armijo, 2012) refer to the school climate "as the perception that the educational players have in regards to the interpersonal relationships that establish the school context (at a classroom or school-wide level) and the context or setting in which these interactions take place" (Cornejo \& Redondo, 2001, p. 16).

\subsection{Revision of Literature and Instruments in the Area of School Climate}

For the elaboration of the instrument, the most renowned instruments of this area were considered, which are: The Organizational Climate Description Questionnaire (OCDQ), developed original in the United States (Halpin \& Croft, 1963), and validated for the Spanish population at the University of Sevilla (López, 1989). The Organizational Climate for Educational Institutions (OCEI) Questionnaire developed originally by Litwin and Stringer (1968) and validated in Chile by the College of Psychology at the Catholic University of Chile (Justiniano, 1984). Also, the School Social Climate Scale (ECLIS) developed by Arón, Milicic, and Armijo (2012). And the Social Climate Scale (SCS) developed in the University of Stanford, California (Moos, Moos \& Tricket, 1989), which was adapted to the Spanish population by Gómez, Valle and Pulido (1989). Dimensions and reagents form these instruments were considered as inputs for the elaboration of the School Climate of 
Educational Institutions instrument.

\section{Method}

This investigation possesses a quantitative design. The elaboration and validation procedure of the instrument, School Climate in Educational Organizations (SCEO), was carried out in three stages which considered: (1) discriminative elaboration of items, (2) evaluation of internal consistency levels; and (3) evaluation of the validity of the instrument (López, 2000; Guerra, Rodríguez, Morales, \& Betta, 2010).

The first and second stages were concentrated in the phase of preliminary construction and analysis of the instrument, considering the following phases: a) design of items and dimensions, taking as orientation some reagents of the instruments $O C D Q, O C E I$, and $S C S$ as recently mentioned; b) linguistic adaption; c) validation of content, submission to the judgment of experts, which permitted the modification of language, form and content elements of the scale and sub-scales; d) pilot application and statistical analysis, the initial instrument, composed of 56 items, was applied a sample of 404 subjects, therein developing factorial analysis with the purpose of reproducing its extension and permitting the elimination of 11 items, which presented a lower load factor.

The third stage considered the general application of the definitive instrument, now composed by 45 items, and applied a sample of 549 subjects for the study of the psychometric properties of reliability, using Cronbach's alpha coefficient, and the validity of the internal structure of the instrument by exploratory factorial analysis. This article focuses on this stage of final investigation.

\subsection{Participants}

The selection of the educational establishments was of natural intention, and the schools were selected according to the objectives of the investigation (Flick, 2004; Hernández, Fernández, \& Baptista, 2003; Albert, 2007). Voluntary participation of the participants of the investigation was achieved, and was authorized and coordinated by the director of every educational establishment. There was a participation of 549 teachers and directives, whose ages varied between 25-55 years with a total of 387 women and 162 men, who belonged to 42 urban establishments in the city of Temuco, Chile. The distribution of the participants and their demographic characteristics can be observed in Table 1 .

Table 1. Demographic characteristics of participants

\begin{tabular}{lccc}
\hline Characteristic & & $\mathrm{N}^{\circ}$ & $\%$ \\
\hline Gender & Men & 207 & 37,8 \\
Position & Women & 342 & 62,2 \\
& Teachers & 406 & 73,9 \\
Age & Directives & 143 & 26,1 \\
& $25-39$ years & 262 & 47,7 \\
Type of school & $40-55$ years & 287 & 52,2 \\
& Public & 196 & 35,70 \\
& Semi-private & 183 & 33,33 \\
Years of experience & Private & 170 & 30,96 \\
& 3-10 years & 183 & 33,33 \\
& $11-20$ years & 161 & 29,32 \\
& More than 20 years & 205 & 37,34 \\
\hline
\end{tabular}

\subsection{Instrument}

The instrument is composed by three dimensions, the first called the Relationship Dimension, subdivided in three sub-dimensions with a total of 16 items, the second called the Organization Dimension, subdivided in two sub-dimensions with a total of 14 items, and the third called Conditioning Elements Dimension, subdivided into three sub-dimensions with a total of 15 items (see Table 2). 
Table 2. Structure of the instrument

\begin{tabular}{lll}
\hline Dimension & Subdimension & Items \\
\hline Relationship & Teacher-student and parent relationships & $01,04,05,06,07,08,09$ \\
& Teacher-teacher relationships & $10,12,13,14,15,16,17,23,24$ \\
Organization & Teacher-director relationships & $25,26,27,27,29,30,31,35,36$ \\
& Influence of structural elements & $20,32,33,38,39$ \\
Conditioning Elements & Teacher motivation & $02,03,44,45$ \\
& Teacher work style & $11,18,19,21,22$ \\
& Teacher needs & $34,37,40,41,42,43$ \\
\hline
\end{tabular}

The items which have an inverse order in the instrument (with the purpose of interpretation) are: $4,8,12,13,14$, $15,18,19,20,24,26,29,30,32,33,34,37,39,40,41,44$.

The instrument measures categorical variables using a Likert-type scale of collective responses, whose possible answers go from 1 to 4, (1) Strongly disagree, (2) Disagree, (3) Agree and (4) Strongly Agree, not considering a central category.

\subsection{Analysis}

The study of the validation and reliability of the study of the instrument considered analysis of the data with the statistical process SPSS in its version 20. To estimate the reliability or internal consistency of the scale the Cronbach alpha coefficient was employed, and was applied to the final factorial structure, as well as the general set of items grouped in each factor of the final factorial arrangement. The analysis of validity of the internal structure of the instrument was calculated using the exploratory factorial analysis, with the extraction of main components and Varimax rotation method, through the principal components method the underlying factorial structure was identified, or rather, the groups of items observed in the interior of the dimension of the study. The exploratory analysis was achieved by searching for the smallest quantity of factors which explained the largest quantity of variance and at the same time were interpretable and congruent with the construct (Morales, 2013). The sample fit index and the assumptions of sphericity were calculated.

\section{Results}

\subsection{Analysis of Instrument Reliability}

The study of internal consistency of the instrument conducted for the total scale and for each dimension of the instrument produced high levels through the Cronbach alpha coefficient, such as that the value that represents the reliability of the total scale, 0.935 , the value with which it is possible to affirm that the structure of the instrument is dependable. Then the values that represent the reliability reached by every dimension of the instrument, give the following results:

1) The Relationship Dimension (which combines the sub-dimensions of peer relationships, teacher-student relationships and teacher-parent relationships) obtained an alpha of 0.861 .

2) The Organization Dimension (which combines the sub-dimensions of influence of direction, and influence of the formal structure) obtained an alpha of 0.854 .

3) Finally the Conditioning Elements Dimension (which combines the sub-dimensions of teacher motivation, teacher work style, and teacher needs) obtained an alpha of 0.804 .

\subsection{Exploratory Factor Analysis}

Before the factorial analysis of the educational climate instrument, an analysis was performed of the adequacy of sample measurement KMO (Kaiser-Meyer-Olkin) $=0.925$, this being the optimum and significant statistic. Assuming that Bartlett's sphericity test is true, and being statistically significant to report a value Chi - square of 9989.581 and a significance of $\mathrm{p}<0.01$ which permits the conclusion, together with the KMO, that the variables are correlated and it is thus possible to achieve the factorization.

The Exploratory Factorial Analysis performed, with extraction of principal components and the method of Varimax rotation, which gave a factorial structure of 9 factors, which through conceptual analysis were reduced to 7 factors. Each item was included on the scale in coherence with statistical and theoretical analysis. These are shown in the following table (see Table 3). 
Table 3. Exploratory factorial analysis values

\begin{tabular}{|c|c|c|c|c|c|c|c|}
\hline \multicolumn{8}{|c|}{ Component } \\
\hline & 1 & 2 & 3 & 4 & 5 & 6 & 7 \\
\hline v1 & .088 & -.033 & .025 & .172 & .226 & .138 & -.065 \\
\hline v2 & .130 & .342 & .085 & .078 & .159 & -.024 & .074 \\
\hline v3 & .116 & .318 & .126 & .086 & .104 & .066 & .145 \\
\hline v4 & .285 & -.021 & .172 & -.004 & .631 & .152 & .150 \\
\hline v5 & -.006 & .196 & .009 & .071 & .679 & -.057 & -.033 \\
\hline v6 & .111 & .202 & .079 & .067 & .704 & .027 & .112 \\
\hline v7 & .111 & .293 & .109 & .063 & .547 & .098 & .240 \\
\hline v8 & .365 & .004 & .270 & .014 & .109 & -.107 & .564 \\
\hline v9 & .103 & .281 & .002 & .091 & .230 & .158 & .637 \\
\hline v10 & .367 & .396 & .110 & .168 & .047 & .058 & .292 \\
\hline v11 & .247 & .421 & -.055 & .181 & .037 & .314 & .262 \\
\hline v12 & .653 & .104 & .175 & .112 & .045 & .034 & .119 \\
\hline v13 & .815 & .131 & .200 & .054 & .078 & .053 & .027 \\
\hline v14 & .803 & .135 & .151 & .089 & .015 & .022 & .083 \\
\hline v15 & .763 & .167 & .186 & .101 & -.016 & -.012 & .052 \\
\hline v16 & .230 & .558 & .051 & .174 & .271 & -.159 & .090 \\
\hline v17 & .128 & .645 & .105 & -.017 & .195 & .008 & .112 \\
\hline v18 & .558 & .169 & .275 & .074 & .189 & -.129 & .021 \\
\hline v19 & .698 & .195 & .177 & .070 & .111 & .110 & .093 \\
\hline v20 & .680 & .238 & .262 & .034 & .055 & .005 & -.083 \\
\hline v21 & .237 & .733 & -.023 & .186 & -.012 & .231 & .064 \\
\hline v22 & .238 & .758 & -.026 & .111 & .096 & .141 & -.061 \\
\hline v23 & .321 & .648 & .064 & .164 & .024 & .099 & .113 \\
\hline v24 & .636 & .098 & .290 & .033 & .097 & .012 & .138 \\
\hline v25 & .097 & .469 & .222 & .401 & .136 & .028 & -.109 \\
\hline v26 & .265 & -.072 & .456 & .310 & .103 & -.099 & .187 \\
\hline v27 & .172 & .246 & .147 & .757 & .052 & .082 & .082 \\
\hline v28 & .163 & .203 & .120 & .724 & .036 & .042 & .177 \\
\hline v29 & .226 & .057 & .601 & .180 & .018 & -.244 & .006 \\
\hline v30 & .397 & .213 & .510 & .103 & .055 & -.156 & .180 \\
\hline v31 & .055 & .251 & .098 & .637 & .067 & .067 & -.082 \\
\hline v32 & .213 & .124 & .662 & .047 & -.074 & -.053 & .234 \\
\hline v33 & .218 & .121 & .653 & .097 & -.003 & .136 & .059 \\
\hline v34 & .266 & .091 & .645 & .068 & -.035 & .194 & .077 \\
\hline
\end{tabular}




\begin{tabular}{|c|c|c|c|c|c|c|c|}
\hline v35 & .033 & .312 & -.048 & .420 & -.074 & .495 & -.026 \\
\hline v36 & .007 & .457 & .302 & .403 & .028 & -.062 & -.023 \\
\hline v37 & .030 & .065 & .526 & -.283 & .081 & .166 & .120 \\
\hline v38 & .031 & .522 & .143 & .265 & .060 & -.006 & .074 \\
\hline v39 & .400 & .043 & .514 & .326 & .113 & .031 & -.059 \\
\hline v40 & .326 & .060 & .649 & .147 & .217 & .086 & -.189 \\
\hline v41 & .292 & -.033 & .631 & .109 & .235 & .172 & -.219 \\
\hline v42 & -.125 & .164 & .081 & .130 & .041 & .180 & .047 \\
\hline v43 & -.050 & .263 & .168 & .017 & .088 & .615 & .030 \\
\hline v44 & .256 & -.131 & .371 & .290 & .196 & .381 & .144 \\
\hline v45 & .064 & .423 & .192 & .122 & .231 & .286 & -.077 \\
\hline
\end{tabular}

In the above table one can see 45 items which are distributed according to the first or second highest load among seven factors, whose percentages of variance can be observed in the next table in which seven factors are shown with an accumulative variance of $53.279 \%$ of $100 \%$ of the total explained variance.

Table 4. Factors and percentages of variance

\begin{tabular}{lccl}
\hline Factor & Variance factor & Cumulative variance & Name factor \\
\hline Factor 1 & $27.362 \%$ & ---- & Obstacles in teacher-teacher relationships \\
Factor 2 & $9.040 \%$ & $36.402 \%$ & Facilitators of the teacher-teacher relationship \\
Factor 3 & $4.880 \%$ & $41.282 \%$ & Stressful aspects of the educational climate \\
Factor 4 & $4.301 \%$ & $45.582 \%$ & Influence of director leadership style \\
Factor 5 & $2.988 \%$. & $48.571 \%$ & Influence of the teacher-student relationship \\
Factor 6 & $2.429 \%$. & $51.00 \%$ & Influence of perceived teacher needs \\
Factor 7 & $2.279 \%$. & $53.279 \%$ & Influence of the teacher-parent relationship \\
\hline
\end{tabular}

The above table shows that the Exploratory Factorial Analysis implemented with the Educational Climate instrument and shows that the factorial structure of the instrument is composed of seven key factors. These factors were named based on conceptual elements from Chilean public policies and previous instruments on the field. These are:

The factor $\mathrm{n}^{\circ} 1$ called obstacles in teacher-teacher relationships, explains the $27.362 \%$ of total variability of the instrument.

The factor $\mathrm{n}^{\circ} 2$ called facilitators of the teacher-teacher relationship, indicated by $9.040 \%$ and together with the first factor explains the $36.402 \%$ of the total variability of the instrument.

The factor $\mathrm{n}^{\circ} 3$ called stressful aspects of the educational climate which explains $4.880 \%$ of the total variability of the instrument and together with the aforementioned factors they explain $41.282 \%$ of the total variability of the instrument.

The factor $\mathrm{n}^{\circ} 4$ called influence of director leadership style accounts for $4.301 \%$ and together with the aforementioned factors covers $45.582 \%$ of the total variability of the instrument.

The factor $\mathrm{n}^{\circ} 5$ named influence of the teacher-student relationship indicated by $2.988 \%$, and together with the aforementioned factors represents $48.571 \%$ of the total variability of the instrument.

The factor $\mathrm{n}^{\circ} 6$ called influence of perceived teacher needs represents $2.429 \%$ and together with the other factors a $51 \%$ of the total variability of the instrument.

The factor $n^{\circ} 7$ called influence of the teacher-parent relationship represents $2.279 \%$, and together with the other 
factors explains $53.279 \%$ of the total variability of the instrument.

\section{Discussion}

The study permitted the establishing of reliable and valid psychometric characteristics of the School Climate of Educational Institutions instrument in a population of teachers and directors in Chilean schools. The study shows that the instrument possesses adequate psychometric properties. According to the values found by the Cronbach alpha, a value above a 0.9 should be considered an excellent level of internal reliability, in this setting, the instrument has shown an excellent level of internal consistency, presented by a reliability of the total scale of 0.935 , which permits the conclusion that the instrument is dependable.

The three dimensions that make up the instrument (Relationships, Organization and Conditioning Elements) equally show a Cronbach alpha of $0.861,0.854$ and 0.804 respectively, demonstrating good levels of internal consistency.

Seven factors were obtained formed by items which are conceptually and statistically consistent. The seven factors represent the key aspects that make up the climate in educational organizations, represented in obstacle and facilitator elements of the teacher-teacher relationship, stressful aspects of the educational climate--as seen from the negative influence of leadership and direction, the structure and the resources-- the teacher-student relationship, the influence of the leadership, and the influence of the teacher-parent relationships, such as that the factorial analysis obtained has presented an important coincidence with the original theoretical structure of the instrument. The total variance percentage accumulated $53.279 \%$ of the total explained variance, which would suggest that those evaluated by this test are represented in only one dimension.

The first factor obtained called "obstacles in teacher-teacher relationships" assembles the identification of aspects that interfere negatively in the relationship with the teacher staff. Then the second factor obtained called "Facilitators of the teacher-teacher relationship" assembles criteria the positively influences the relationships of the teachers. These items, after being processed by the Varimax method of rotation, were shown in factors $\mathrm{n}^{\circ} 1$ and 2, coinciding with a theoretical perspective, and with the origin of the structure of the instrument. Both factors which represent the "characteristics of the interpersonal relationships developed between the teacher staff constitute the factor which will weigh more when the educational climate is studied (Becerra, 2006; López, 2000). This sustains that the characteristics of the interactions that are created among the teaching staff possess a determining influence on the appreciation of the educational climate.

If we continue the discussion from the analysis of the relationships of the participants, it is shown that the fourth factor called "influence of direction", assembles together linked aspects of the influence that the leader has on the educational climate. These items, after being processesed using the Varimax rotation method, were concentrated on a common factor empirically consistent with previous experiences which establish leadership as a key factor, of significant weight, for the educational climate (Becerra, 2006; López, 2000). The aforementioned is also coherent from the theoretical empirical perspective in which distinct studies refer to the determining influence that the direction style or educational leadership possess for the climate of the school, and in general for the life of the organization (MINEDUC, 2014).

The analysis of the relationship of the educational participants is complete when considering the factors of "teacher-student relationships" and "teacher-parent relationships" which when being processed by the Varimax rotation method were assembled together with the factors $n^{\circ} 5$ and 7 respectively. Previous investigations have already moved ahead, in which the perception of the educational climate and the relationship between these two players, achieves low weights, always receiving more importance in the perception of educational climate in relation to the relationships among the teaching staff, and between those who exercise a leadership or directive role (Becerra, 2006; Martín-Bris, 2000).

Finally, the factors which connotate elements of dysfunctional school systems in educational climate, upon being processed by the Varimax rotation method they were concentrated in the factor $\mathrm{n}^{\circ} 3$ called "dysfunctional aspects for the educational climate", which joins criteria of negative influence linked to the direction and structure of the school, such as schedule overload, work overload, lack of time, lack of recognition and rigidity of the supervision. Equally, the sixth factor called "Perceived teacher needs" joins criteria of negative influence on the school climate linked to the disposition and use of material resources, and the lack of labor stability for the teaching staff. These elements represent stressful aspects for the educational climate, and are theoretically consistent to consider with dysfunctional elements of the school system that negativey influence the perception of the psychosocial well-being of the staff, which has been presented in specialized literature regarding this phenomenon. 
The seven factors indicated represent key aspects that allow understanding the climate, considering aspects which are typical of the interaction among teachers, directives, students and parents, as well as considering the importance of some structural organizational variables that occur on a daily basis as obstacles and facilitators of school climate.

\section{Conclusion}

The study demonstrates that the School Climate of Educational Institutions instrument poses adequate psychometric characteristics. It shows an excellent level of internal consistency, presenting a reliability of the total scale of 0.935 , which permits the conclusion that the instrument is dependable. Likewise the three dimensions that are included (Relationships, Organization, and Conditioning Elements) show adequate levels of internal consistency.

In addition seven factors were obtained made up of conceptually and statistically consistent items. Those seven factors represent the key aspects that make up the climate in educational organizations.

The instrument constitutes a tool of extensive benefits for professionals that work in educational administration, as well as those who try to contribute to the improvement of education, considering the educational climate as a key aspect for the results obtained by the school organization.

\section{Acknowledgments}

We acknowledge research grants DGIUCT 200953 (General Direction of Research at Universidad Católica in Temuco-Chile, which financed the current study.

\section{References}

Ainscow, M., \& Miles, S. (2008). Making education for all inclusive: Where next? Prospects, 38(1), 15-34. http://dx.doi.org/10.1007/s11125-008-9055-0

Alarcón, C., \& Romagnoli, C. (2006). El clima escolar como plataforma de cambio. Programa Valoras UC, Editorial PUC. Retrieved from http://valoras.uc.cl/wp-content/uploads/2010/09/clima_social_escolar.pdf

Albert, M. J. (2007). La Investigación Educativa. España: McGrawHill.

Arón, A.M., Milicic, N., \& Armijo, I. (2012). Clima Social Escolar: Una escala de Evaluación de Clima Social Escolar, ECLIS. Universitas Psychologica, 11(3), 803-813.

Becerra, S. (2006). Cómo podemos intervenir para fortalecer el clima educativo en tiempos de innovación? Revista Estudios Pedagógicos, 32(2), 47-71. http://dx.doi.org/10.4067/s0718-07052006000200003

Becerra, S., Muñoz, F., \& Riquelme, R. (2015). School Violence and School Coexistence Management: Unresolved Challenges. Journal Procedia-Social and Behavioral Sciences, 190, 156-163. http://dx.doi.org/10.1016/j.sbspro.2015.05.030

Becerra, S., Sánchez, V., \& Tapia, C. (2007). El Clima Educativo: una deuda en la salud mental del docente chileno. Revista Castalia, 9(12), 63-75.

Bermejo, L., \& Prieto, M. (2005). Malestar docente y creencias de autoeficacia del profesor. Revista Española de Pedagogía, 232, 493-510. http://dx.doi.org/10.14201/aula201521245257

Boulifa, K., \& Kaaouachi, A. (2014). The Relationship between Students' Perception of Being Safe in School, Principals' Perception of School Climate and Science Achievement in TIMSS 2007: A Comparison between Urban and Rural Public School. International Education Studies, 8, 100-112. http://dx.doi.org/10.5539/ies.v8n1p100

Bush, T., \& Glover, D. (2012). Distributed leadership in action. School Leadership and Management, 32(1), 21-36. http://dx.doi.org/10.1080/13632434.2011.642354

Caso, J., \& Fierro, C. (2013). Evaluación y análisis de prácticas de intercambio y convivencia escolar. Revista Iberoamericana de Evaluación Educativa, 6(2), 7-12.

Caso, J., Díaz, C., \& Chaparro, A. (2013). Aplicación de un procedimiento para la optimización de la medida de la convivencia escolar. Revista Iberoamericana de Evaluación Educativa, 6(2), 137-145.

Cassasus, J. (2003). La escuela y la (des)igualdad. Santiago: LOM Ediciones.

Chile, Ministerio de Educación. (2005). Términos de Referencia Curso- Taller Formación de Directores y Equipos de Gestión 2006. Santiago, Chile: CPEIP.

Claro, S., \& Bedregal, P. (2003). Aproximación al estado de salud mental del profesorado de Puente Alto. 
Revista Médica de Chile, 131(2), 159-167. http://dx.doi.org/10.4067/s0034-98872003000200005

Cornejo, R., \& Redondo, J. (2001). El Clima Escolar Percibido por los Alumnos de Enseñanza Media. Ultima Década, 4(15). http://dx.doi.org/10.4067/s0718-22362001000200002

Esteve, J. M. (2006) Las emociones en el ejercicio práctico de la docencia. Teoría de la Educación, 18, 85-107.

Fierro, C. (2013). Convivencia inclusiva y democrática. Una perspectiva para gestionar la seguridad escolar. Sinéctica, (40), 1-18. Retrieved from http://www.scielo.org.mx/scielo.php?script=sci_arttext\&pid=S1665109X2013000100005\&lng $=$ es\&tlng=es

Flick, U. (2004). Introduction to qualitative research. Madrid: Ediciones Morata.

Gómez, D. E., Valle, A., \& Pulido, M. T. (1989). Evaluación y estructura del clima socioescolar en alumnos de Enseñanza Media de Galicia. Revista de Psicología General y Aplicada, 42(3), 367-376.

González, A. (2004). Evaluación del clima escolar como factor de calidad. Madrid: La Muralla, S.A.

González, L. (2006). Gestión y convivencia democrática en la escuela. In J. Ruz (Ed.), Convivencia y calidad de la educación (OEI, pp. 201-214).

Guerra, C., Rodríguez, K., Morales, G., \& Betta, R. (2010). Validación Preliminar de la Escala de Conductas de Autocuidado para Psicólogos Clínicos. Psykhe, 17(2). Retrieved from http://www.scielo.cl/scielo.php?script=sci_arttext\&pid=S0718-22282008000200006\&lng=es\&nrm=iso

Halpin, A., \& Croft, D. (1963). The organizational climate of schools. Chicago: Midwest Administration Center, University of Chicago.

Hernández, R., Fernández, C., \& Baptista, P. (2003). Metodología de la Investigación (3rd ed.). México: McGraw-Hill.

Justiniano, S. (1984). Cuestionario para medir clima organizacional en instituciones educacionales (Unpublished master's thesis). Universidad Católica de Chile, Santiago, Chile.

Litwin, G. H., \& Stringer, R. A. (1968). Motivation and Organizational Climate. Cambridge, Massachusetts: Harvard Business School.

López, J. (1989). Un Instrumento de Diagnóstico del Clima Organizativo en los Centros Escolares. Paper presented at the II Jornadas de Prácticas de Enseñanza, Poio, Pontevedra.

López, J. (2000). El Asesor Como Analista Institucional. In C. Marcelo, \& J. López (Coord), Asesoramiento Curricular y Organizativo. Barcelona: Ariel.

López, V., Bilbao, M., Ascorra, P., Moya, I., \& Morales, M. (2014). School Climate Scale: Spanish Adaptation and Validation in Chilean Students. Universitas Psychologica, 13(3), 1111-1122. http://dx.doi.org/10.11144/Javeriana.UPSY13-3.ecea

Martin-Bris, M. (2000). Clima de trabajo y organizaciones que aprenden. Educar, 27, 103-117.

Milicic, N., Arón, A. M., \& Pesce, C. (2003). Violencia en la Escuela. La percepción de los Directores. Psykhe, 12(1), 177-194.

Ministry of Education-Chile. (2014). SIMCE learning outcomes and development indicators. Santiago: Chilean Government.

Moos, R., Moos, B., \& Tricket, E. (1989). Escalas de clima social. Madrid: Consulting Psychologists Press.

Morales, P. (2013). El análisis factorial en la construcción e interpretación de tests, escalas y cuestionarios. Madrid: Universidad Pontificia Comillas.

Moriana, J. A., \& Herruzo, J. (2004). Estrés y burnout en profesores. Internacional Journal of Clinical and Health Psychology, 4, 597-621. Retrieved from http://www.aepc.es/ijchp/articulos_pdf/ijchp-126.pdf

Murillo, P., \& Becerra, S. (2009). Las percepciones del clima escolar por directivos, docentes y alumnado mediante el empleo de «redes semánticas naturales». Su importancia en la gestión de centros educativos. Revista de Educación, 350, 375-399. Retrieved from http://www.revistaeducacion.educacion.es/re350/re350_16.pdf

Organización de las Naciones Unidas para la Educación, Ciencia y Cultura. (2005). Condiciones de trabajo y salud docente: Estudios de caso en Argentina, Chile, Ecuador, México, Perú y Uruguay. Santiago: ONU

Thapa, A., Cohen, J., Guffey, S., \& Higgins-D’Alessandro, A. (2013). A Review of School Climate Research. 


\section{Appendix A}

\section{Validated Scale: School Climate of Educational Institutions}

1. As teachers, we feel that the students treat us with empathy.

2. As teachers, we feel proud of being educators.

3. As teachers, we carry out our work with enthusiasm and satisfaction.

4. The student's lack of discipline is an aspect that causes tension in the school environment.

5. In our school, our students respect us.

6. In our school, the relationships we have with our students are agreeable.

7. The communication between the students and the teachers is good.

8. In our school there are major conflicts between the parents and teachers.

9. In our school, the communication between the teachers and parents is good.

10. In our school, the teachers feel that their colleagues treat them with empathy.

11. In our school, we quickly recognize our colleagues' achievements.

12. In this establishment we need to show more concern for our colleagues.

13. In our school there are some demonstrations of jealousy amongst colleagues.

14. In our school there is generally a lot of gossip amongst colleagues.

15. In this establishment, teachers frequently spread rumors.

16. In this establishment, as teachers we feel our colleagues respect us.

17. The relationships amongst colleagues are generally characterized as pleasant.

18. As teachers we feel that there is a tendency towards competitiveness amongst colleagues.

19. Amongst colleagues, there is a lack of cooperation in daily work.

20. The subgroups that exist amongst the teachers affect the workplace's organization.

21. Colleagues share their work and support each other in new projects.

22. Colleagues coordinate amongst themselves to facilitate teaching duties.

23. In our establishment there is a prevailing sense of warmth and sociability amongst colleagues.

24. There are frequent conflicts and arguments between colleagues.

25. The relationship between administrators and teachers is quite close.

26. Our work as teachers is barely recognized by the administrators.

27. The administrative team is open to listening to our suggestions and demands as teachers.

28. We can freely talk with our administrative team, even when we are having problems.

29. The administrators supervise us in a strict and rigid manner.

30. There are frequent relational conflicts and arguments between colleagues administrators.

31. The administrators avoid being authoritative and promote reaching agreements.

32. There is never an opportunity to fully celebrate important dates or events.

33. Teachers' rest times during recess are frequently not respected.

34. As teachers, we don't have a space to get together in an informal way over longer periods of time.

35. The administrators often give us feedback on our performance.

36. As teachers we generally feel respected by the administrators.

37. The physical space we teach in doesn't really facilitate our teaching practice.

38. Everyone knows what his or her responsibilities include.

39. At this school there are too many administrative barriers, rules and regulations to comply with. 
40. As teachers, we feel we are constantly under pressure due to our extensive workload.

41. As teachers, we feel that our schedules are too full.

42. At this school, as teachers, we feel we have stability and security in our jobs.

43. As teachers, we have access to enough material resources to carry out our jobs.

44. Here we feel that our expectations in terms of professional development aren't met.

45. As teachers, we feel content with belonging to this institution.

\section{Copyrights}

Copyright for this article is retained by the author(s), with first publication rights granted to the journal.

This is an open-access article distributed under the terms and conditions of the Creative Commons Attribution license (http://creativecommons.org/licenses/by/3.0/). 